Anne Murphy

\title{
Sufis, Jogis, and the question of religious difference: individualisation in early modern Punjab
}

\section{Introduction}

We open with a verse from a mid-18th century Punjabi-language poetic narrative by Waris Shah, named for its heroine, Hìr:

\begin{abstract}
hauka phire dè்dā pindāǹ vicha sāre "āo, kise faqūra je hovnā je” mañga khāvnā kama nah kāja karnā, na ko chārnā, te nah hī chovnā je żarā kana parāike svāha malnī gūrū sāre hī jaga dā hovnā je nah dīhār nah kasaba rozgāra karnā bādshāha phira mufta dā hovnā je nahìn denī vadhāì phira jamne dì kise moe nūn mūla nah rovnā je mañga khāvnā ate masìta sonā nah kujha bovnā te nah kujha lovnā je nāle mañgnā te nāle ghornāi den dāra nah kise da hovnā je khushī āpnī uṭhnā miyāì vāriša ate āpnī nīnda hī sovnā je (Šābir 1986, 144f., v. 254). ${ }^{1}$

[Ranjha] calls out, wandering in all the villages, "Come, if you will be a Fakir!" To eat what one begs for, and not to have to work: no grazing of cattle, no milking. Just bore through the ears and cover the body with ash: with that, become the Guru of the world!

By day, no need to work and toil; free then of the Shah himself. ${ }^{2}$

No need to celebrate births, and no need to mourn at death.

Eat what one begs for, and sleep in a mosque! Do not plant anything and do not reap! Asking from others with a terrible grimace, with nothing to give back!

Oh Waris! To wake when one likes, and to sleep when one is tired!
\end{abstract}

1 There is no critical edition of Waris Shah's text; the version used here, edited by Śarif Šābir 1986, is well regarded (see comment, for example, in Shackle 1992, 259, fn 32; personal communication, Denis Matringe, September 2015). For limited discussion of the manuscript tradition and some exemplary printed editions, see Shackle ‘Transition' and Deol 2002, 151f.; and Matringe 2003, 228-30. I make occasional reference to another version (Padam 1998 [1977]) when a preferred reading is found.

2 Nadho Shāh is given in Šābir 1986 but in Padam (1998 [1977], 122, v. 252) this is bādshāh (and the verb is jovna $\bar{a}$. The Padam is a more accessible reading, so is used here.

Note: Thank you to Martin Fuchs, Antje Linkenbach, Aditya Malik, Beatrice Renzi, Jörg Rüpke, and others involved in the KFG program at the Max-Weber-Kolleg for excellent feedback on an earlier version of this essay, and for an enriching stay at the Kolleg from May to July 2017. 
This verse provides a typical description of an ascetic: begging for alms, living outside of conventional norms, and smeared with ash; it also features attributes specific to the Nath Yogis - practitioners of Hatha Yoga, Shaivite ascetics, but more generally known in the vernaculars of north India as 'Jogis' - such as the wearing of mudrān் or large earrings bored through the center of the ear. But there is much more at work here than immediately meets the eye. This essay will explore what is at stake in a portrayal like this, and argue that the idea of religious individualisation - the subject of this volume - can provide a valuable tool for its analysis, focusing not so much the individual per se, but instead on individualisation as a process or, perhaps even more, a kind of possibility, as a comparative rubric across religions that undergirds this representation.

This portrayal takes place within a love story, a narrative known in Persian and Punjabi as a qissā. Ranjha ${ }^{3}$, the lover of Hir, is the figure described in the verse. ${ }^{4}$ Ranjha has taken on the guise of a Jogi after losing Hir in an arranged marriage to another. Her family had rejected him as a potential suitor due to his less elite caste status and his relative lack of wealth: he did not fare well when property was distributed among him and his brothers at his father's death, and while he is also from a Jat (agricultural caste) family, like Hir, his lineage was deemed less elite than hers. This series of events brings us to this verse, where we see Ranjha becoming a faqīr, a holy man (an originally Persian term) as a Muslim, but also as a Jogi. We can see this, indeed, in this verse, where he speaks in a complex and mixed idiom of the holy man or faqir, mobilizing the imagery associated with the Nath Yogi tradition, while referring to taking refuge in a mosque. This persona is inhabited by a Muslim main character out of despair over losing his love (and, as will be discussed, is a self-conscious ruse to get her back - the theme of the inauthentic or disingenuous Jogi, is important here).

How do we explain the ease with which Ranjha takes on the identity of a Jogi, identified as he is in the text, as Muslim? What is at stake in such a move across, between and within religious communities?

Such questions are not of merely scholarly or historical interest. Anyone who works on the region from which this text hails, Punjab, faces a dilemma: how do we account for the violence within this once integrated society of Hindus, Sikhs,

3 The hero's given name is Dhīdo, but he is generally referred to by his caste name, Rānjihā, a Jat clan from a place called Takhat Hazara. With diacritics, the name is Rānjihā.

4 There are many versions of the Hir-Ranjha story, including the sixteenth century version by Damodar, and brief mention in the Vars of Bhai Gurdas, and in the Dasam Granth. The narrative inspired a large number of $k \bar{a} f \bar{i}$ or poems by Bulhe Shah, as well as several narrative versions in Persian. See Shackle 1992, 244-7, and footnotes 4, 5, 9, 10 on these pages. See also Murphy and Shahbaz, forthcoming. 
Muslims, Christians, and others, as it turned violently upon itself in 1947 at the division of the region into the new countries of India and Pakistan, shattering Punjabiness (or 'Punjabiyat') as a lived experience? This haunts everything we do in this field, no matter what our temporal focus. On the one hand, we see the fact of an integrated culture. Farina Mir's (2010) recent work, for example, excavates the shared 'Punjabi literary formation', as she calls it, that brought people together in the late colonial period, challenging a prior scholarly preoccupation with explicitly religious reformist and agonistic dynamics in the period. She is right to do so, for the cultural production that she highlights - colonial period versions of the qissā or 'narrative literature' tradition of Punjab that are part of the larger tradition that the text we examine hails from - does articulate a shared sense of 'Punjabiyat' or Punjabiness. Indeed, Waris Shah's Hìr is perhaps the most quintessentially Punjabi text one might identify, the text that the anticolonial revolutionary Udham Singh sought to take his oath on when at trial; Singh was executed by the British in London for the 1940 murder of the former Lieutenant Governor of Punjab, Michael O'Dwyer, who had held office at the time of the infamous Jallianawala Bagh incident, when British troops fired on peaceful demonstrators in Amritsar, Punjab in 1919. He had at that time renamed himself Muhammad Singh Azād, taking on both a Muslim name and a Sikh name, with a surname, $A z \bar{a} d$, that means 'freedom' (Bhardwaj 2007; Fenech 2002). Waris Shah's text is thus central, as Jeevan Deol $(2002,142)$ has noted, to the 'Punjabi episteme', and continues to be a valued cultural resource on both sides of the Indo-Pakistan border, as is demonstrated by its availability in both scripts that Punjabi is written in: Gurmukhi, on the Indian side and associated strongly with Sikh tradition, and the Perso-Arabic script, popularly known as Shahmukhi in Punjabi, on the Pakistan side (Murphy 2018a). On the other hand, at the same time that we have this shared commitment to 'Punjabiyat', we have the harsh reality of violence and division, now engraved in a border that separates a once integrated culture into two nationalised, religiously exclusive ones. While religion has thus taken precedence in defining difference within Punjabi society, there are and were also differences along the lines of class and caste (and the oft-forgotten category of gender, too, which has a particular significance in the text in question that will be touched on here). I will try to reconnect these social categories here, in at least preliminary terms, alongside a consideration of the religious (On gender, see Murphy 2018c.).

The problem, although stark in Punjab given the history of Partition, is however one that reaches far beyond it. The problem is a broad one: how do we account for the shared religious worlds that characterised the pre-modern period in South Asia overall (recognizing at times that religious difference could result in conflict at very particular historical junctures and locations). Is this pre-modern 
religious world the utopia we seek, a kind of precolonial oasis outside of the storm of colonially constructed and now post-colonial conflict, as it has been construed in the work of some scholars and cultural critics? (Murphy 2015).

This problem is also a historiographical one, because the problem of exactly how to describe in historical terms the complex cultural and religious formations of South Asia continues to challenge scholarship. A wealth of scholarship has for instance highlighted the recent provenance of the term and idea of 'Hindu', noting its changing nature and, I think most usefully, its contrastive rather than substantive sense (Ernst 2004 [1994], 22ff.; Lorenzen 1999; Pennington 2005). Thus, for example, we can see in eighteenth century Punjabi Braj texts that express Sikh communitarian perspectives that Sikhs were contained within a sense of 'Hindu' in broad contrastive terms, at the same time that Sikh positions were portrayed as representing a clearly separate religious/cultural tradition alongside other traditions that were portrayed as similarly distinct (some of which are now included under the umbrella term 'Hindu') (Murphy 2012a). The term, in such texts, seems to function akin to the term 'gentile' in the West, indicating what one is not, not what one is (Lorenzen 1999, 639f.). We do see the consolidation of a caste-inflected and simultaneously inclusive and exclusive Hindu identity in the eighteenth century (inclusive in its attempts to articulate forms of authority that would apply broadly, and exclusive in its imposition of caste and other regulatory devices that would define membership along hierarchical lines), reflecting the articulation of a range of religious identities in the period, only some of which were integrated into this newly emergent identity (Hare 2011; Hawley 2011; Horstmann 2011; Horstmann 2009; Pinch 1999). We see therefore the rise of Vaishnav bhakti as part of a broader adoption of a supralocal and less tantric/yogic form of religious life in the late medieval/early modern period, and a kind of Vaishnava-Mughal cosmopolitan synthesis, as described in different but important ways a decade ago in the work of Kumkum Chatterjee, Heidi Pauwels, and William Pinch, and more recently elaborated by others (Pinch 2006; Burchett 2012, 40, 318; Pauwels 2009; Hawley 2015, $75,124,225)$. Chatterjee has argued that 'the cosmopolitanisms' of this period that interest her 'resulted from the use of Vaishnava elements certainly, but Vaishnava elements which were conjoined to Mughal and Rajput elements as well' (Chatterjee 2009, 150). She thus views Vaishnavism as a 'trans-regional phenomenon that developed, matured and grew stronger during the period of the later Delhi sultanate as well as the Mughal empire' (ibid., 151). This corresponded with increasingly centralizing and categorizing discourses within elite philosophical circles as well, as the work of Andrew Nicholson (2010) has shown. So, we do see historically a move towards increasing definition and consolidation, but one which simultaneously never achieves full descriptive applicability; that only occurred when such processes were accelerated, generalised, and bureaucratized by the exigencies of 
colonial rule, when incorporated and homogenised religious identities were given unprecedented political weight within the mechanisms of British colonial governance, such as the census and the legal management of religious sites (Jones 1981; Murphy 2012b, Chap. 6).

\section{A history of crossing}

Full description and analysis of what pre-existed and accompanied such consolidation, however, has proven elusive. In the early 1990s, in keeping with a general celebration of cultural hybridity characteristic of scholarly work at that time, Harjot Oberoi argued that in the pre-modern period 'most Sikhs moved in and out of multiple identities grounded in local, regional, religious, and secular realities. Consequently, the boundaries between what could be seen as the Sikh "great" and "little" traditions were highly blurred: several competing definitions of who constituted a Sikh were possible’ (Oberoi 1994, 24f.).

This 'older pluralist paradigm of Sikh faith', he argued, 'was displaced forever and replaced by a highly uniform Sikh identity, the one we know today as modern Sikhism' (Oberoi 1994, 25). Oberoi's idealised portrait of this 'alternative' world was in many ways overdrawn, disallowing the historical fact of the unfolding articulation of Sikh and other religious identities; this was its flaw. Yet, Oberoi's argument captured something extremely important about the transformations associated with the nineteenth century, and the shape of shared cultural and religious practices that do not fit modern formulations of exclusive identity formation. There is something about this that makes sense: we know both intuitively and in scholarly terms that people perform particular identities and positions in ways that are context-dependent, non-monolithic and variable, and it is not surprising to surmise that this is a basic feature of human self- and social-formation. This is perhaps as much a feature of pre-modernity as it is of modernity. We should expect therefore to see diverse, changing, pragmatic and idiosyncratic choices made by individuals in complex religious environments.

It is thus somewhat surprising that such an interpretation has been rejected wholesale by a range of scholars writing in the last decade. For example, in addressing the 'two genres of religious poetry' in 'two distinct traditions' (Sikh and Islamic) that provide us with our evidence of early Punjabi, senior scholar of Punjabi, Sindhi, and related traditions Christopher Shackle argues that while the interests of these traditions are in some ways strikingly parallel, Punjabi Sufi poetry cannot be 'properly understood without wider reference to the larger religious and literary traditions by which it is so intimately informed': that related to 
Islam (Shackle 2015, xi). (This counters an earlier argument of Shackle's (2000), where he found that class supersedes religious difference in this genre.) Francesca Orsini expressed a parallel view in an insightful essay on the multi-lingual nature of north Indian literary production - work that is extremely valuable for understanding the complex religious moorings of Punjabi cultural production to argue that 'the alternative to selective single-language literary histories [...] is not a narrative of "composite culture"' (Orsini 2012, 242). Both narratives of difference and of syncretism and 'composite culture', she argues elsewhere, 'have had to exclude much of literary production to prove their point', but she also notes that 'an alternative to those flawed narratives is yet to emerge' (Orsini 2010,1). This is in keeping with a range of other scholarship. Scholar of Bengali Vaishnava and Islamic traditions, Tony Stewart (2001), provided a trenchant critique of the idea of syncretism, arguing in part that the term fails in explanatory terms because it wrongly assumes fully formed cultural/linguistic/religious identities that are then blended (see also overview in Hatley 2007, 360ff.). This has been reiterated by many others since, with related rationale, such as by Carl Ernst (2003), who also usefully critiques the deeply problematic idea of 'influence' in historiographical contexts. Farina Mir's exploration of the practice of shrine veneration shared by members of different faith communities was similarly framed as a critique of the idea of the syncretic, although there is more to her argument that will be discussed below (Mir 2006; 2010, Chap. 5) Yet, even as Stewart's critique is widely cited in works I refer to here, which reject the usefulness of the idea of the 'composite' and syncretic, this denial all too often can end with reassertion of just the kinds of reified identities that Stewart argues against. This is not to say that there are no merits to this work; far to the contrary, there is much of value here. Timothy Dobe speaks of 'code-switching' as a way of addressing the complexity of affiliations and practices, which he rightly argues has the advantage of 'assuming that individuals are self-conscious and aware of difference'. This certainly does allow for a valuable interpretive frame for understanding certain kinds of cross-fertilisation and crossing. At the same time, however, he complicates the very notion of such a difference in code, itself, in his valuable discussion of the complex configuration of the faqiir figure (Dobe 2015, 25).

One important example of this tension, particularly important for the argument I will pursue further here regarding the romantic hero Ranjha, as a yogi, is the very important case of the Hindavi prem-ākhyān tradition, which was written in an early Hindavi vernacular from the 14th to the 16th centuries, with themes and tropes from diverse traditions we now call 'Hindu' and with Sufi mystical underpinnings. Aditya Behl has argued that this work 'embodies an Indian Islamic literary tradition, the acculturation of a monotheistic faith and a literary model into a local landscape', where the Chishti Sufis 'promoted a surface 
liberalism of outlook' that simultaneously asserted their own hegemony (Behl 2012, 19, 22). He is able to accept literary mixing, arguing that the 'formation of creolised or mixed literary genres implies a world of conversion and conflict, dialogue and intermingling' (ibid., 13). In religious terms, however, he frames the Islamic as taking precedence. As I will make clear at the end of the paper, I do not in the end reject Behl's stance; there are real reasons for taking it (which is why speaking of a fuzzy 'sharing' is so problematic). Here, I note the stance and its limitations: such criticism of 'syncretism' or mixing, or the 'composite' or amalgamation of cultures, can end in the reification of just such identities that are questioned within the critique, to leave us with that which is already formed, and which in the stronger forms of the argument adheres to itself fully in engagement with the 'other'. There are, no doubt, examples of just this very dynamic in the early modern period. We see this in Sikh mobilisations of Nath imagery, for example, whereby Guru Nanak takes a Nath vision of the esoteric quest for transcendence and uses it to assert a Sikh exoteric parallel practice, such as in the Sidh Gost section of the Adi Granth (for background, see Nayar, Sandhu 2007). Here, clearly, a Sikh articulation is being served by reference to Nath practices. But this is not how all such representations work. To argue that they do work this way suggests the radical incompatibility of religions and civilisations - a 'clash of civilisations' perhaps, in the terms described by Samuel Huntington (1993). It seems clear, therefore, that some further work is required, as Orsini suggests. How do we move beyond both an idealised but vague and ahistorical notion of the 'composite' and what has amounted to the reinscription of boundaries, to negotiate a more nuanced position between these two poles that have thus far been staked out?

How differently can this problem be configured, if we focus on points of intersection instead? As Nile Green has suggested, in line with Stewart's argument, we are missing something in asking how Hindus and Muslims came together at various points when 'the people we label under these terms had perhaps not yet come to see themselves as "apart" in the first place, at least in terms of a doctrine and practice model of "religion"' (Green 2008a, 1056). Commonality, not identity, might be a more fruitful way to imagine what has brought people together. This is Farina Mir's approach to understanding shared piety: she sees piety functioning 'in its own terms', 'as a parallel arena of belief', unconcerned with conventional religious difference (Mir 2010, 177, 182). My effort in this essay is parallel, but distinct. I argue here that the idea of religious individualisation, the topic of this volume, has something to offer us in the study of pre-modern, pre-communalised (that is, pre-reified and agonistic religious) South Asian cultural forms, and that in turn these forms have something to offer the KFG as a study of the applicability 
of its theoretical premises. ${ }^{5}$ Attention to the dynamic of religious individualisation reveals not ill-defined mixing or a blending, or 'fuzziness', as described recently by Andrew Nicholson (2013), but instead a concerted and joint effort at something else, a kind of 'entangled history' where 'ideas and practices that strengthen or trigger individualisation processes are transferred' and experienced as a single thing (Fuchs et al. 2016, 11). This is what matters: the connections among the traditions brought together in the faqir : the articulation of an individualizing ethos functioning to challenge religious and other (such as caste, gender) communitarian formations, at the same time that these formations are recognised and represented. In the context of Punjab, this ethos was positioned outside of communitarian formations that had stronger institutional foundation. This, I will suggest at the close of the essay, is also one of the reasons why 'Punjabiyat', or a shared cultural and religious ethos, did not prevail in providing an alternative in 1947.

First some context. If we are to look back in time for religious individualisation in Punjab, the Sufi poets, such as Shah Hussain and Bulhe Shah, provide ample evidence. Here, in Bulhe Shah, we can see a direct relationship between individual experience and the breaking down of religious community barriers (e.g. Shah 2015, Lyric no. 40, p. 68f.). Bhakti or devotional thought and practice in both Sufi contexts and beyond both challenged and necessitated certain kinds of individualisation, both encouraging (indeed requiring) the articulation of an individual self that then must be overcome (Fuchs et al. 2016, 11). Angelika Malinar has noted that "the "individual self" received a new recognition in the context of bhakti', and that 'further religious pluralisation seems particularly intense with respect to bhakti communities and can be considered as resulting from individualisation process with respect to doctrine as well as practices', fed by both asceticism and devotion, two forces that remained in tension through the early modern period (Malinar 2015, 406; see also Pinch 2006). Martin Fuchs' contribution to this volume directly assesses this issue. Along similar lines, Imre Bangha (2000) has similarly argued that 'one can perceive a subtle move towards the importance of individual life and sentiments in various South Asian literary cultures between the sixteenth and eighteenth centuries', in both Bhakti and secular contexts. This is the world out of which figures such as Waris Shah, and his poem Hirr, emerge.

The figure of the Jogi in this qissā by Waris Shah bears the traces of these historical dynamics among religions in South Asia - within a long history of contact,

5 While certainly it would be absurd to argue that there was no communal conflict (that is, along religious lines) prior to the colonial period, the evidence shows that the politicisation of religion within colonial administration was unprecedented, and that it had profound effect. The argument for a 'pre-history' of communalism in Bayly (1985) does not account sufficiently for the systemic way religion was mobilized to govern by the state under British rule. 
and of transitions among them. ${ }^{6}$ As White well notes, while later commentators and scholars have privileged 'disengagement of the senses, mind, and intellect from the outside world in favor of concentration on the transcendent person within' as a descriptive norm of what it means to do yoga, Jogis themselves have not been portrayed as 'introversive or introspective - but rather always as extrovert, if not predatory' (White 2009, 38). Jogis instead were very much of the world, on their own terms, with some engaging in warfare, state formation, and family life (Lorenzen 1978; Pinch 2006; White 2009, 223). At the same time, they did occupy a place outside of 'convention': White has them called “"others within”, standing as a constructed antitype to the good people of ordered society'. It is not surprising that individualizing forces can be linked to this kind of contingent position, on the outside (White 2009, 199).

There is a wide provenance for Sufi/Jogi synthesis, and it draws on diverse representations of the Jogi figure across traditions - including within Hindu traditions themselves. Nicholson has thus argued that 'Yoga in classical India was like open-source software. It was distributed freely and modified by different authors, all competing to come up with the best version for liberation' (Nicholson 2013, 498). We have a precursor to what we see in Hì in the Sufi-Jogi figure at the centre of the Sufi prem-ākhyān or 'love story' tradition that Aditya Behl has examined at length, where the transformation of the hero into a Jogi in order to achieve his love is one of the 'formulaic elements' Behl identifies as common to the four texts he examines from the 14th to the 16th centuries, as a means to describe a Sufi mystical journey (Behl 2012, 23, 71, 95). He is clear, as I have mentioned, about the ways this synthesis is articulated: 'the poet uses the highest spiritual value in yogic language to suggest a Persian mystical concept, reimagining Islamic ideology in Indian dress' and 'Daud [author of one of the works] turns this symbolic vocabulary away from the Nath-panth and uses it to express the Sufi mortification of the self' (Behl 2012, 96). Here, Yogic themes are portrayed as a 'dress' that nonetheless expresses core or inherent Islamic ideas. In similar terms, Shaman Hatley discusses Bengali Sufi Yogic material by arguing that 'although the sources for this yoga are clearly indigenous, primarily the Natha cult and at a later stage Sahajiya Vaisnavism, Muslim authors encode their disciplines within Islamic doctrinal categories and articulate them as integral elements of a Sufi praxis regimen' (Hatley 2007, 352). The use of Jog in Qutḅan's Mirigāvatī (1503), and indeed the entire genre, 'here reimagines Sufi ideology

6 One of the most commonly portrayed interactions not only among Sufis and Jogis, but with other figures (such as the Sikh Gurus) was the miracle contest (Murphy 2012a; White 2009, 200; Burchett 2011). 
within an Indian landscape and reshapes rasa poetics in Sufi terms' (Behl 2012, 301). The Sufic mobilisation of yogic ideas and practice is most vividly seen in Shattari Sufi practice (Behl 2012, 240, 304; see also Ernst 2005, 29f.). Yet, as noted above, Behl sees this as still embedded within a hierarchy: 'The characters in the story, and by implication the Sufis, are not exactly yogis; they are like yogis, only better, as they can use yogic practices and language framed within a Sufi romantic poetics. Through this seeming logic [the author of Padmāvat,] Jāyasī spells out the Chishti Sufi claim to superiority within a local religious landscape' (Behl 2012, 176, see also 171).

There is a broad relationship here between Sufism and Yoga that speaks to this set of representations. As Ernst has explicated in great detail in recent scholarship, examination of the evidence of exchange between Sufism and Yoga reveals that 'generalities about Hinduism and Islam are relatively useless for shedding light on the significance of the text' he examines (Ernst 2003, 205; see also Ernst 2005, 42). Something else, then, is at stake in the act of cultural translation and exchange. Yoga is so fully translated into Islamicate (not always strictly Islamic) terms and ideas that a lack of a sense of 'radical difference' emerges, Ernst (2003, 223) argues, and thus, in one example explored by Ernst, Nizām al-Dīn Awrangābādī (d. 1730), in a comprehensive account of Chishti meditation techniques, 'fits yogic techniques into an Islamic framework that supplies the intentions and ultimate meaning that yogis may have been unaware of' and includes an array of hatha yoga mantras that had for a long period been adopted to 'Islamic themes and Sufi practices' (Ernst 1999, 355). Thus, 'yogic practices could be assimilated into a Sufi perspective without much effort. In short, there is no Sufi concept of yoga as a completely separate system. It would probably be safe to say that there was likewise no hatha yoga concept of Sufism as a separate entity' (Ernst 2005, 42). For Awrangābādī, 'yogic practices of non-Muslim ascetics are simply one more set of parallel techniques that can be added to the mix' (Ernst 1999, 357). Ernst has shown that this is the normative frame for the understanding and integration of yoga and its practices within Islamic understanding, drawing 'upon frameworks - political, philosophical, theological, or occult that were well domesticated in their own culture' (Ernst 2016, 423). Indeed, as he notes, this is the nature of universals: that they are framed within the language of the speaker. At the same time, the finding of such commonalities is itself historically constituted. As Nile Green has aptly shown, by the colonial period in India's increasingly communalised colonial public sphere [...] Yogis and Sufis articulated rival forms of physical culture and religious identity in response to the wider crisis facing precolonial Indian lifeworlds' (Green 2008b, 285; see also 292, 307ff.). This inaugurated a period of denial of exchange, despite the fact that it was clear that 'on the ground' Sufis and Yogis were in frequent contact and 
did cross-participate - there were Muslim Nath yogi orders that continued into the colonial period, and the colonial period meditational manuals explored by Green, while governed by a logic of difference between Sufism and Yoga, shared 'transcendent moral and ethereal goals for the bodily practices they promoted'. Commonality remained, even as difference was asserted.

We have travelled far, but now return, to the example with which we opened: the portrayal of Ranjha as a Jogi. If we can see in lyrical Bhakti poetry such as that by Bulhe Shah formations of religious individualisation, what do we find here? There is some of the mystical in Waris Shah's text, but not a great deal. When Hir is challenged regarding her love for Ranjha, and is forced to face the Qazi who would wed her to another, she invokes religious claims as well as the sanctity of love to support her position (Šābir 1986, v. 208; she does this again in Šābir 1986, v. 217). She tells us 'Where the love of Ranjha has taken up residence, there can be no sway of the Kheras', utilizing the same verb used at the beginning of the work to describe what happens when Sufi patriarch and probably most beloved Sufi saint of the region Baba Farid takes up residence in Punjab. At the end of the tale, we hear Ranjha's commentary on his state at losing Hir, with lamentation at vijog or loss/separation: Ranjha does appear at times ready to truly embrace being a Jogi, in despair, and even exhibits some of the miraculous powers associated with this role (Šābir 1986, v. 607). ${ }^{8}$ So we see devotional elements, and there are certainly also allegorical ways to read the text, as scholars have highlighted, but these function on a high, summary level (Deol 2002, 146f.).

Much more than these elements, however, we have the mundane, the everyday, and intense interactions between people, often in conflict. At times, the most appropriate way to think about this text may not be through analogies with high Sufi literature and the classical Persian masnavi, as is formally appropriate in terms of genre, but Parsi and other forms of traditional theatre, such as Nautanki (indeed, there are moments when Bollywood does not seem far off). Satire, irony, and farce recur. Najm Hosain Syed, one of the foremost Punjabi literary critics in Pakistan, has thus called its primary mode 'comedy': a 'comedy, though

7 Green 2008b, 289 for quote, 290ff. and particularly 309ff. on the growing denial of shared participation; see Ernst 2005, 38 on Muslim yogi orders.

8 Ranjha promises to cure Hir (after this verse for some time the issue of Yogis and their medicinal practices and their efficacy are debated); it seems he almost is a Jogi (Šābir 1986, v. 371). Ranjha proves himself to be a yogi to Sahiti through a simple test, and asks her to tell Hir to come. She agrees, and asks him for a boon, recognizing his power (Šābir 1986, v. 501). It is almost as if Ranjha is a Fakir at times: he says he has had enough of the world (Šābir 1986, v. 577). Later, Ranjha prays (Šābir 1986, v. 586) and Sahiti’s love, Murad, appears (Šābir 1986, v. 587). After this, the two couples escape. 
unrestrained to the extent of boisterousness, still more a means of irony than hilarity' (Syed 2006 [1968], 45). ${ }^{9}$ How else can one explain the fantastic portrayal of young women physically attacking Kaido, Hir's uncle, and destroying his belongings, because he has told Hir's parents about her activities with Ranjha? Waris Shah describes this as being like the attack of the armies of Lahore on the city of Mathura, to the south of Delhi (Šābir 1986, 76, v. 141). How else do we view the portrayal of young women engaging in uncontrolled behaviour in public, wandering in the wild on their own, and the violent girl-fight between Hir and Sahiti, her sister-in-law, about Ranjha? (Šābir 1986, v. 548-58, v. 416-8). These instances contribute to the ethos of critique that pervades the text, as well as its sense of humour. We thus see a portrayal of the faqiir as a commonality, across religious idioms, in a spirit of alterity, but also, as the absurd. Indeed, Kaido, Hir's evil uncle, is also portrayed as a mendicant or faqī. Why is he so upset when Hir's friends attack him, after he has revealed Hir and Ranjha's secret love to her parents? He complains that his opium and drugs have been stolen from him! (Šābir 1986, 78, v. 144). Within the farce and mocking we see consistently one element: the articulation of social hierarchies and rules, in tension, and in rupture. Indeed, this is inherent in particular to the Jogi himself, Ranjha, who is questioned and accused of being a 'fake fakir' throughout, reiterating a trope about the suspect holy man that has a long pedigree in early modern South Asia, which some scholars have argued is tied to a turn away from yoga towards devotional forms of religious expression, as discussed above, although this should not be too simply drawn (On farce and satire in Waris Shah's text, see Murphy 2018c).

My argument here is, I'll note, diverges from Jeevan Deol's: he highlights an 'erotic counter-current' that he believes 'forms a part of the poem's larger discourse of social critique, which has as its main target the hypocrisy of organised religion' (Deol 2002, 146). I agree to a degree with this assessment, which Ishwar Dayal Gaur more recently also asserts; both Gaur and Deol focus on famous passages portraying Ranjha's conflict with a mullah at a mosque, and Hir's debate with the Qazi brought in by her parents to bring her in line, as exemplifying an explicit and direct challenge to religious authority (Gaur 2009, 103-6, 164; Šābir 1986, v. 37-42; the incident in the mosque is also discussed at some length by Syed (2006 [1968] 48ff.). As Deol puts it, 'throughout the qissah, qazis and mullas are associated with bad consequences, and they often have a considerable hand in bringing those consequences about' (Deol 2002, 164-8; see 165 for quote). However, I would qualify this position; although certainly Ranjha's exchange with the mullah mocks his authority, at other points Islamic religious figures

9 For more on irony, see Shackle 1992, 249. 
are portrayed in a different light. A Qazi or legal specialist, called upon by Hir's parents, is shown as attempting to mediate between Hir and her parents, noting the very real danger Hir is in, disobeying her parents and the norms of patriarchal society. The Qazi certainly exhorts Hir to adhere to social norms, but also clearly states that this is in order to save her life. ${ }^{10}$ Her family is portrayed, instead, as the source of threat (Šābir 1986, v. 209-16). We can see this in this example from the text:

qāžż ākhiyā khauf khudā dā kar māpe chiha charhe chāhe mārnī ge terī kiyāriyoñ jībh khichā kaṛhan māre sharam de khūn guzārnī ge jis waqat asān ditā chā fatwaī us waqat hī pār utārnī ge māñ ākhdī loṛh khudā dā je tikhe shaukh dede vekh pärnī ge variš shāh kar tarak burāiāàn tūin nahīn aga de vicha nighārnī ge (Šābir 1986, v. 118).

The Qazi said, "Be fearful of God! If your parents are angered, then you will be killed. Your tongue needs to be pulled out from your throat, otherwise your shameful blood will be shed.

The moment I give judgement, at that instant your time will come. Your mother says that this is a calamity of God, and look, sharp impertinence tears at you.” Waris Shah, renounce your bad deeds, so that you do not fall into fire.

Regarding this 'erotic counter-current', Deol further argues that the sexual nature of the text is 'counterbalanced by a refusal to acknowledge explicitly the sexual nature of the relationship between Hir and Ranjha' (Deol 2002, 161). Such a characterisation of the sexualisation of Hir is untenable. ${ }^{11}$ Firstly, explicit sexual depictions are not outside the classical and the literary as Deol asserts; as Behl's account makes clear, in the prem-ākhyān tradition explicit sexuality was embraced. Hir and Ranjha also very clearly do engage in sexual intimacy; there is an involved description of Hir at the end of the text, after she visits Ranjha the faqi $r$, where all the marks of her love-making draw attention (Šābir 1986, v. 514-38). The debate regarding gender functions also far more broadly than just in relation to Hir's sexuality - the figure of Sahiti, Hir's sister-in-law, reveals this (about whom more below). The portrayal of Ranjha's appearance, throughout the text, and its reception by the Jogis in homoerotic terms, also adds far more complexity than a focus

10 Islamic norms have in the past and present offered less harsh realities for women than those in accordance with 'custom' in Punjab and other parts of Northwest India/Pakistan. For discussion of this relationship in the British period, see Gilmartin 1988; see Nelson 2011 for the extension of this important discussion from the colonial period to the end of the twentieth century in Pakistani Punjab. Shah observes the tension between Islamic and rural/tribal systems in Sindh today (Shah 2016, 10).

11 On sexuality and gender overall in Waris Shah's text, see Murphy 2018c. and Mann 2018. 
on Hir alone allows. ${ }^{12}$ Deol has emphasised this highly sexual nature of the text, but this is only one aspect of what has been called its 'earthy' nature, as has been noted above with the discussion of violence and the absurd (Deol 2002, 158f.). The portrayals of Hir's sexuality, as well as Ranjha's, thus contribute to an overall sense of farce and rupture that pervades the work, taking a common highly sexualised portrayal of the heroine just a bit further, with a measure of mirth and farce, just as all the interactions in the work go just a step too far (Murphy 2018c). These features contribute, to be sure, to the ethos of critique that pervades the text, but the centre of that critique is found most volubly in the figure of the Jogi, and in the debates about gender that are linked to it. All of it, however, proceeds with a measure of mirth and satire.

The problematic and probably inauthentic status of Ranjha as a faqiir is a central theme of the work. As he tells us: 'sānūin joga dī rījha tadokanì sì jadori hìra syāla mahobat kītì' ('I have had a passion for jog ever since I fell in love with Hir of Syaal') (Šābir 1986, 163, v. 284). ${ }^{13}$ It is she, in fact, who tells him to become a Jogi and return to her, after her parents and the Qazi (as it is portrayed in the story) decide to marry her off: 'tainūin hāl dì gala main likha ghaliān, turata ho faqīra tè àonā $\bar{\imath} \mid$ kise jogi the jāìke banen chelā, svāh lāìke kan parāonā ì' ('I will write to you about everything! Go and become a Fakir and return! Go and make yourself a Chela at some Yogi's centre, put ash on your body and pierce your ears [as the Nath Jogis do]!') (Šābir 1986, 125, v. 223). This begins an important theme: is Ranjha a real Jogi, or not? His indeterminate status as a holy man, as well as the theme of the 'fake faqī' overall, are important themes. Immediately following this is a long series of critical comments about Jats, the caste that both the heroine and hero belong to, albeit with the hero from a less elite lineage within the caste group (e.g. Šābir 1986, v. 225-7, v. 600). This is a persistent feature of this text: commentary about social categories and their critique. Elsewhere I have called attention to the congruences between this preoccupation with caste and discourses over caste that are visible in Sikh texts dated to the 18th century. One such text, the Gurbilās Patshāhì Das, challenges the hegemony of caste and articulates new kinds of social order within the Sikh community (Murphy 2018b).

12 The seeming acceptance of Ranjha by Balnath brings on disgust by the other jogis: Look, he is ready to give Yoga to this pretty boy! (Šābir 1986, 153f., v. 269). The other yogis complain, and the Yogis abandon their yogic implements (selhīān topiāñ and mundarāin) and get violent (Šābir 1986, v. 271). (In between, Ranjha accuses them of slander: Šābir 1986, v. 270.) Then the Yogis repent and get Ranjha ready for his initiation.

13 However, as Christipher Shackle points out, Ranjha is described as a faqir as soon as he leaves his home on the quest that will bring him to Hir, so in his adoption of full jogi status only means that 'his implicit identity' has been 'explicitly revealed' (Shackle 1992, 257). 
While some texts of this period in the same and other genres reassert the importance of caste - in keeping with casteist discourses that prevailed in Vaishnava contexts, for example, in the seventeenth and eighteenth centuries, discussed above - others continued to challenge these formulations. In Waris Shah, we see both the articulation of operative social categories and their critique; the text asserts Jat social power, but often the stance towards Jats is also mocking and teasing (e.g. Šābir 1986, 162f., v. 283).

The text features an extensive description of the interaction of Ranjha with his would-be teacher, Balnath, the beginning of a long and varied engagement with the description of Jogi practices and what membership in the Jogi order entails:

țile jāìke jogī the hatha jợe, sānūn àpnā karo faqūra sāìn tere darasa dīdāra de dekhne nūin, āyā desa pardesa main chīra sāìn šidaqa dhāra ke nāla yaqina āyā, asīin chelare te tusīin pīr sāìn bādshāh sachā rab 'ālmāñ dā, faqar us de hain wazìr sāīn bināin murshidān rāha nah hatha āve, dudha bājha nah hove hai khïra sāìn yāda haqa dī šabara taslīma nihchā, tusāñ jaga de nāl kīh sīra sāìn faqara kula jahān dā āsrā hai, tāba'a faqar dī pīra te mīra sāìn merā māuñ nah bāpa nah sāka koì chāchā tāīā nah bhain nah vīr sāìn duniyā vich hāin bahuta udāsa hoyā, pairon sā dịion lāh zanjīr sāìn tainūn chha ḍa ke jāin main hora kisa the, nazara āūnā hain zạhirā pīr sāīn (Šābir 1986, 145, v. 255).

Going to the place of the Jogis with hands in supplication, he said "Make us one of your own, lord Faqìr!

In order to have sight of you, I have come from across lands far and wide. In faith I have come to believe that I am the student and you are the pir God is the true king of all the worlds, and the faqir is his minister. Without a guide one cannot find the path: how can one make rice pudding without milk? Remembering the truth, with faith, respect and patience, what do you have to do with the world?

The lineage of faqirs is the support of the world, obedient to the chief and leader of the faqir way

It is as if I have no father or mother, no relative, no uncles, no sister or brother.

I have become detached from the world, take these shackles off of my feet Besides you, where do I have to go? You, Lord, are True Pir to me.”

Dubious at first about Ranjha's interest in the Jogi life, Balnath questions him (Šābir 1986, v. 256, 258). This leads into an extensive description of Yogi life and beliefs, something that is repeated later. We see a great deal more on Jogis and their beliefs when Ranjha finally comes to Hir's village as a Jogi, and enters into a lively and extensive debate with Sahiti, Hir's sister-in-law; here, the origins of Yoga are also discussed (Šābir 1986, v. 350). We do therefore see treatment of doctrinal religious content, as well as genuine interest in renunciation, such as Ran- 
jha's declaration of the temporary and pointless nature of the world: 'khwāba rāta dī jaga diyā sabha galān dhana māla nūn mūla nah jhūriye jù' ('All these matters of the world are like a night's dream; we must not lament the price of all our riches') (Šābir 1986, 147, v. 259; see also v. 257, 261).

Balnath describes the life of jog as follows (giving here a short sample from a long soliloquy):

\author{
aisa joga de vā'ade bahut aukhe nād anhat te suna vajāūnā vo \\ jogī jañgam gaudaṛi jațā dhārī muṇ̃ī nirmalā bhekh vațāūnā vo \\ tāṛ̂̀ lāìke nātha dā dhīāna dharnā dasvīn dvāra hai sāsa chaṛhāvnā vo \\ [...] \\ udiān-bāsī jatī satī jogī jhāta istrī te nahin pāvanā vo \\ lakha khūbšūrata pari hūra hove żarā jīv nahīn bharmāvnā vo \\ karida mūla te posta afīma bajiyā nashah khāike mast ho jāvanā vo \\ [...]
}

kāma krodha te lobha huñkāra marana jogī khāka dara khāka ho jāvanā vo

ranān் ghora dā gāūndā phiren் vahshī tainūn aukhaṛā joga kamāvanā vo

iha joga hai kama nirāsiyāñ dā tusāñ jațān kīh joga thoñ pāvanā vo (Šābir 1986, 150, v. 264).

These pledges of yoga are very difficult, to play the unstruck tune of the infinite, oh!

To exchange for the pure dress of the sect of Jogis: carrying dreadlocks on the head and the dress of a religious order, oh!

Adopting the stare of meditation, concentrate on the Lord, and raise your breath to the tenth door, oh!

[...]

The true Jogi lives in the forest and does not lay eyes on a woman, oh!

There might be a 100,000 beautiful fairies and nymphs, but do not mislead your life, oh!

Even without marijuana, roots, poppy, and opium, become intoxicated and enjoy! oh!

[...]

Destroying lust, anger, greed and ego, the Jogi becomes dust among dust.

Wandering around singing and staring at women - it is hard for you to earn Joga, oh!

This Joga is for the few without hope in the world. What can a Jat like you hope to gain, oh?

This passage illustrates two debates that are interlinked through the narrative: the relationship between men and women (sexual and otherwise) and what it means to be a Jogi, true and false. Here we see description of the appropriate Jogi attitude towards women - and Balnath's doubts that Ranjha could ever become a proper Jogi as a result. When the Nath leader further instructs Ranjha and directs him to look at women as sister and mother, Ranjha rejects this, invoking his status as a Jaț: 'asīn jața hāñ nạrịyān karanvāle asāin kachkare nahīn purovane n’’ ('We are Jațs! We pull ropes. We don’t string glass pearls!') (Šābir 1986, 162, v. 282). ${ }^{14}$

14 The exact reference of the ropes is ambiguous, suggesting the ropes of cattle, or perhaps the drawstrings of trousers that are commonly worn in Punjab. 
The debate continues until finally higher forces, the mythical painj pir or five holy men, intervene on Ranjha's behalf (ibid., 164f., v. 285).

The exchange between Sahiti, Hir's sister-in-law, and Ranjha comprises a major component of the narrative: 60 verses, with the scene continuing with further conflict among Hir, Sahiti, and Ranjha for more than 50 additional verses (ibid., v. 327-87). ${ }^{15}$ In some ways, Sahiti is the real heroine of the text: she speaks far more than Hir, and hers is a strong and independent voice: Pankaj Singh has called hers 'the loudest and most aggressive voice contesting the idle, impatient, intolerant, egotistical, quarrelsome, boastful, imposter Ranjha' $(2000,62) .{ }^{16}$ She challenges Ranjha in all things, arguing at multiple instances on behalf of women (in contrast to Ranjha, who adopts very critical views of women) (Šābir 1986, v. 353). In this we see the conceptual centre of the work: a debate on the nature of women and men's relationship, and the nature of women and men themselves, alongside the recurrent accusation that Ranjha is not a real Jogi. This debate is prefaced by Ranjha's arrival in the village: he is popular with the young women. When Hir hears of his arrival, she wonders if it is him (ibid., v. 310). The poet describes the varied responses to the Jogi among the women: some trust him, some do not, some are generous, others are not; this is followed by discussion of different kinds of women, by caste (ibid., 191, v. 322, 325). Within a few verses Ranjha and Sahiti are directly at odds, with Sahiti accusing him of knowing Hir and being a fake Jogi (a theme that runs through the work) (ibid., 205, v. 342). The description of types continues, with debate on the nature of men and women and social categories, such as through these words of Ranjha (in which women do not fare well):

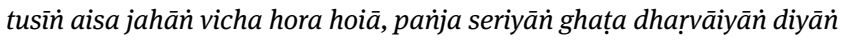
mard hain jahāz nakoiyāin de, ranāń beriyāin hain burāiyān diyāin haṛa māsa halāla harāma kapan, ehah kohāriyāàn hain qašāiyāàn diyā̄n (Šābir 1986, v. 353).

You are different in this world, you come up short by 5 units of measure Men are vessels of goodness, and women are vessels of badness [...]. Chopping up bones and meat without regard for Halal and Haram, these [women] are the axes of butchers!

15 Deol sees the debates between Ranjha and Sahiti as only sexual, but this I think misses their full content $(2002,162)$; he talks only briefly about Sahiti's criticism of Ranjha as a faqir, and not about their debates about gender $(2002,164)$.

16 Her view contrasts starkly with that of Syed, for whom Ranjha is 'the essential human being [...] shorn of all recommendations of money or influence' and is 'the touchstone for the world' (Syed 2006 [1968], 53, 57). 
In this we see the conceptual centre of the work: a debate on the nature of women and men, and their relationships, alongside the recurrent doubt that Ranjha is not a real jogi.

Hir and Ranjha achieve their goal in the end: after Hir and Ranjha escape and are caught, they make a successful appeal to a prince for mercy (Šābir 1986, v. 593). This victory is fleeting, however, since Hir's family murders her to prevent their marriage. Hir and Ranjha's almost-success, however, comes through Hir's intercession: it is Hir who curses the town (her, not Ranjha) (ibid., v. 608). Ranjha only helps her enact her curse (ibid., v. 611). Of course, he gets credit for the curse, being the faqì (or, so it seems) (ibid., v. 613). Who has the power here? Deol argues that Hir's curse is ineffective without Ranjha's help - that 'the world will only heed the words of Ranjha' - but I do not see this incident in these terms (Deol 2002, 158). The text at its very end calls this into question, even as the story quickly ends in Hir's death, and then Ranjha's.

\section{Beyond/within the 'composite' and the problem of comparison}

What do we see in Waris Shah's Hìr? Firstly, we see a range of debates around caste, gender, and status, in jest and in mocking. We see a challenge to religious authority, as highlighted by prior scholars Deol and Gaur, but this reflects a larger questioning of social hierarchies overall. This indeterminacy of social position is most centrally articulated in the status of the Jogi and the theme of the fake faqir, linked to the debate about the falsity of conventions and critique of authority. We also see a debate about gender, which does not centre around sexuality primarily (as Deol 2002 argues), but around a comparison between men and women that is in turn linked to a challenge to social conventions and authority overall.

It is clear that what is at issue in Sufi Yogic transformations such as we see here is not the naming of religion per se. The aim of this essay is to suggest what might be named in its stead. Fuchs has argued that individualisation represents an attempt by social actors to fight and overcome conditions that limit or constrain them with regard to their spiritual as also their political wants and needs, their search for self-realisation, or even exclude them from participation in (religious as well as non-religious) communal life and from liberation' (Fuchs 2015, 336). We can see in this text, in this struggle against convention and authority, and the fluidity of movement in and out of social roles, the kind of individualisation Fuchs describes. What we see in Hìr therefore are processes of individualisation that are both religious and social, reflecting a variety of operative norms 
and diverse but shared religious individualizing processes (Malinar 2015, 387). The social critique in Waris Shah's text is paralleled by a critique of caste across the board in other texts of this period, as has been noted, so we can see this as broadly applicable to the period: the eighteenth century was characterised by violence and change, as centralised Mughal power waned and successors vied for power in Punjab (and elsewhere). The religious and social individualisation visible in the text under examination reflects this environment. We must therefore argue for modification of Mir's claim that the dynamics she sees in colonial period versions of the Hir-Ranjha story reflect the unique pressures of that period, 'the contemporary significance and reworking of social structures under colonialism [...] [and the] expression of anxieties produced by the social mobility induced by colonial rule' (Mir 2010, 132). We can see a similar dynamic, and movement towards religious individualisation, happening at this crucial juncture of the eighteenth century, amidst another period of tremendous social change. This allows us to see that the religious crossing we see is secondary to the common articulation of religious individualisation that this text describes, across social and religious roles, even as those roles themselves are described. Bernd-Christian Otto has described four aspects of individualisation: (1) enhanced ideas about individual choices/options, (2) a focus on the self or on creativity; (3) deviance and critique which can include 'openly criticizing established religious norms, concepts, persons and/or institutions' and (4) a focus on experience (inwardness, spiritual transformation, the move toward enlightenment - the link to bhakti or devotional traditions, mentioned earlier) (Otto 2017, 33-36). We can see aspects of all of these dynamics here. Religious individualisation is what links Jogi with faqi $r$, here, and both to a set of challenges to social norms and hierarchies.

What is at stake in the mixing of religious idioms here - that problematic 'composite culture' that needs to be explained today - is a drive towards religious and social individualisation, common across religious identities (and problematizing other social identities, such as caste and gender). It is the mobilisation of different technologies of individualisation that is at stake in the capacious choices that are being represented. As with bhakti, the choice to cross boundaries is linked not to an amorphous and ill-defined 'composite' culture (as has been rightly critiqued) but to the strategic destabilisation of authorities, hierarchies, and categories of meaning in order to foreground a form of critique, a kind of social and individual possibility, as an aspect of this early modern moment of religious and social articulation. A vision of alterity is embraced within this process of individualisation, and as such it depends as much on those very boundaries as it denies them, allowing us to account both for both the articulation of boundaries and their denial (instead of claiming, as the more assertive argument for the 'composite' did, the fuzziness of things in broad terms). Frances Robinson in a recent essay has argued that 'Muslim 
societies across the world have been subject to a prolonged and increasingly deeply felt process of renewal' since the eighteenth century, but reflecting a longer dynamic (Robinson 2008, 259f.). This discussion attempts to bring some historical specificity to one instance of renewal, in Punjab, in the eighteenth century, before its modern forms that Robinson and many others have detailed.

The religious individualisation detailed here functions in particular with respect to the cultural resources of early Punjabi as a language and literature positioned in interstitial locations, rather than in courtly and institutional religious contexts, in the early modern period. This can help us to understand in a new way cultural production in early modern Punjabi outside of the court patronage, which has been associated with the achievement of literary vernacular cultural production in the subcontinent (e.g. Busch 2011). These questions, I believe, must fundamentally inform our understanding of religious identity in Punjab and the emergence of the language of Punjabi as a literary vernacular in the early modern period, and as a language of literature on the outside (Murphy 2019).

There are dangers to this argument, however, and I am well aware of them. First is the problem of any attempt to look across cultures/histories/religions to understand parallels. This argument can be seen to be akin to the designation of an underspecified 'mystical', for example, as a common religious core, regardless of historical difference, through the claim that the mystical is beyond description. If we fail to attempt comparison, however, we lack the ability to discern any explanatory or analytical mechanisms that 'cross boundaries' - which only reifies those boundaries themselves. This is the problem this essay began with. There clearly was, in short, something to compare and find in common for Sufis and Yogis, at particular times and in particular locations. I hope that the historically specificity engaged here allows us to avoid destructive simplification, to engage comparison in a way that discerns what was visible to some in their own time (regarding common technologies of knowledge production and physical transformation, for example). To put it simply, they have already compared and found commonality. It is a wonder why we have trouble doing so as well.

The second danger is related, although perhaps not in a way that is immediately apparent; it is also particular to the histories and contexts examined. Sufism has often been framed as 'outside' of Islam, as a way of domesticating it within the Indian national imaginary. As Partha Chatterjee noted in 1993, this national imaginary was built on claims to a Hindu classical past; we see the ramifications of this today in India. His words are worthy of long quotation:

The real difficulty was with Islam in India, which could claim, within the same classicizing mode, an alternative classical tradition. The nationalist past had been constructed by the early generation of the Bengali intelligentsia as a "Hindu" past, regardless of the fact that 
the appellation was of recent vintage and that the revivalism chose to define itself by a name given to it by "others". This history of the nation could accommodate Islam only as a foreign element, domesticated by shearing its own lineages of a classical past. Popular Islam could then be incorporated in the national culture in the doubly sanitized form of syncretism.

(Chatterjee 1993, 73f.; see also discussion in Ernst 2005).

This explains Behl's decision to emphasise the Islamic nature of the prem-ākhyān tradition, to combat earlier efforts to 'fit' these texts within a 'Hindi' (not Urdu) literary canon by de-emphasizing their Islamic nature (Behl 2012, Chap. 1). We can see parallels in India today, where the absorption of a de-Islamicised and therefore 'safe' Sufism can accompany the continued exclusion of Muslims. The problematic of the binary of 'composite' vs. reified boundaries possesses urgent contemporary force. For this reason, I do not ultimately reject Behl's characterisation, his efforts to characterise the prem-ākhyān tradition as essentially Muslim. The politics of our day require it.

While terms like 'mysticism' are laden with both theological and ideological content, so too is any explanatory mechanism (and the effort to avoid one). (Green 2008, 1046ff.) The idea of religious individualisation as a process engaged by religious actors can perhaps allow us a heuristic device that moves beyond the binary of the undefined 'composite' and reified identity, to appreciate a shared quest from within. There are two things which save us falling into simplistic evolutionary schema (both those that posit a simple rise or a fall in rationality, individualism or even religious 'purity'): first, that religious individualisation is not a teleological process that reaches somewhere and is finished; instead, it appears in multiple cultural and historical contexts (and thus, for example, might have been a feature of Punjabi, Sufi, or Yogi contexts at multiple points in the past and today; here we name only one); and second, that this is not a simple opposition, that deindividualizing forces always accompany individualizing ones, the striving towards 'traditionality' that Otto speaks of (Otto 2017, 49). These are dynamic relationships, not simple oppositions. Thus, they rely upon each other, and this is why we see so often in Waris Shah's text the articulation of both hegemonic forms of social organisation alongside their critique: the threat of violence against Hir (which eventually is fulfilled) by her family, when she dares to love Ranjha. They discuss violence as a means of reestablishing control, and she asserts the evil of killing daughters (Šābir 1986, v. 115). The social norm and its rupture are both present in the text, side by side. We are meant to sympathise with Hir, perhaps, but we also see the other side.

If we remain aware of the dangers of simplistic formulations along these lines, there is a broader possible explanatory power of this line of inquiry that brings us back to the problem articulated at the opening: the division of Punjab in 1947. A wealth of literature has demonstrated how contingent this division was, 
how it could have gone, until very late in the day, either way. We can perhaps understand what was arrayed against it, through our line of inquiry here. If the cross-religious, the in-between, both as kind of bhakti or devotional experience (as we saw with Bulhe Shah) and as a form of religio-social critique (as with Waris Shah) was tied foundationally to religious individualisation, it was grounded outside of the less individualizing institutional realms that received patronage in the colonial period. At that time, colonial administrative mechanisms encouraged collective organisation that denied the religiously individualist, demanding the designation of exclusionary religious identities, for example, and imposing judgements about the definition of such identities that privileged classical and canonical texts that did not seat or voice the individualizing discourses that were so prevalent in the non-canonical such as Waris Shah. This allows us to think in clearer analytical terms about the forces that failed to prevail in 1947, given that they found no institutional purchase in a colonial environment that theoretically privileged the 'modern' but in practice gave voice to entrenched institutional and communal forces and denied recourse to any discourse of the individualised, marked as that discourse was by 'mixing', by the vernacular. ${ }^{17}$ It was in the colonial period, we must remember, that Sufi ascetics and Nath Jogis came to be seen as competitors, rather than allies. Sikhs, Hindus, Muslims: all were under pressure to deny their points of intersection, and to cleanse themselves of locations where other conversations were ongoing, outside of a clear community definition. Thus we have a way out of the fuzziness of 'composite culture', towards a specific and particular understanding of a capacious vernacular religious positioning on the outside, positioned here as a specific effect of religious individualizing processes that were excluded from power within the colonial frame. This is why shared forces did not find the social power to counter the forces of division that prevailed in 1947, as strong as they were. These particular, individualizing tendencies persist today, within religions ${ }^{18}$ and across them, and particularly within ongoing modern Punjabi vernacular cultural production that exceeds the interests of the state and religious hierarchies alike, across the Indo-Pakistan border (Murphy 2018a). But that is a story for another day.

17 There is a large literature that demonstrates the ways British rule contributed to the construction of "feudal" and non-modern cultural forms; one of the most compelling is Ali 1988.

18 As portrayed in the brilliant trilogy of films by Ajay Bhardwaj 2005; 2007; 2012. 
Note on transliteration: I utilise $\dot{n}$ to indicate nasalisation, except before a labial consonant, both internally and at the end of a word, unless a full na is indicated. Orthographically in the Perso-Arabic script (or Shahmukhi, as it is called in Punjabi), a final nasal is distinguished from a full $n a$, but this is not the case internally (that is, nūn from nūn ghunna); different kinds of nasals are thus not distinguished in Shahmukhi. In Gurmukhi, a distinction is made between nasalisation and internal use of full na, and among different kinds of nasals; most often the distinction is between the dental ( $n a$ ) and retroflex ( $n a$ ) and other forms rarely occur. (Internally, in Gurmukhi, palatal na (indicated by ñ) will be utilised as needed, if reference is made to the Gurmukhi text and the distinction is given). $\mathrm{kh}$ is used for khe, $\dot{z}$ indicates $z \bar{a} \mathrm{l}, \mathrm{z}$ is ze, $\mathrm{zh}$ is zhe, $\mathrm{s}$ indicates se, s indicates $\sin$, sh is shīn, š is swaad, ž indicates $z w \bar{a} d$; t indicates toe and $z$ indicates zoe. $h$ indicates vaḍ̣i he and $\mathrm{h}$ is used for choți he; gh indicates ghain. Otherwise, conventions are as standard for new Indo-Aryan languages, with the standard dot underneath consonants to indicate retroflex sounds. Please note that the gemination so common in Punjabi is almost never indicated in Šābir's text. Certain words will appear incorrect to a Punjabi speaker, as a result; I have not corrected this in the version of the text given here, to retain an accurate representation of the text as published by Šābir. I have however made several transliteration decisions meant to make this text more accessible to a more general audience: the use of ch for the unvoiced palatal unaspirated consonant (necessitating the inelegant chh for the aspirated version, but still more accessible for the non-specialist reader) and sh for shin.

\section{References}

Ali, Imran. 1988. Punjab Under Imperialism: 1885-1947. Princeton: Princeton University Press. Bangha, Imre. 2000. 'New Aesthetics in Eighteenth-century Brajbhasha: Emerging Individualism and a New Concept of Love in Ānandghan's Poetry', http://www.columbia. edu/itc/mealac/pritchett/00urduhindilinks/srffest/txt_bangha_newaesthetics.pdf (last access June 11, 2017).

Bayly, C. A. 1985. 'The Pre-History of "Communalism”? Religious Conflict in India, 1700-1860', Modern Asian Studies 19, 2. 177-203.

Behl, Aditya. 2012. Love's Subtle Magic: An Indian Islamic Literary Tradition, 1379-1545. New York: Oxford University Press.

Bhardwaj, Ajay. 2005. Kitte Mil Ve Mahi (Where The Twain Shall Meet) Film, 70 Minutes. Language: Punjabi with English Subtitles.

Bhardwaj, Ajay. 2007. Rabba Hun Kee Kariye (Thus Departed Our Neighbours) Film, 65 Minutes. Language: Punjabi with English Subtitles.

Bhardwaj, Ajay. 2012. Milange Babe Ratan De Mele Te/Let's Meet at Baba Ratan's Fair. Film, 75 minutes. Language: Punjabi with English Subtitles. 
Burchett, Patton. 2011. 'My Miracle Trumps your Magic: Encounters with Yogis in Sufi and Bhakti Hagiographical Literature.' In Yoga Powers: Extraordinary Capacities Attained through Meditation and Concentration, ed. K. A. Jacobsen, Leiden: Brill. 345-80.

Burchett, Patton. 2012. 'Bhakti Religion and Tantric Magic in Mughal India: Kacchvāhās, Rāmānandīs, and Nāths, circa 1500-1750', Ph.D. dissertation, Columbia University.

Busch, Allison. 2011. Poetry of Kings: The Classical Hindi Literature of Mughal India. New York: Oxford University Press.

Chatterjee, Kumkum. 2009. 'Cultural flows and cosmopolitanism in Mughal India: The Bishnupur Kingdom', The Indian Economic and Social History Review 46, 2. 147-82.

Chatterjee, Partha. 1993. The Nation and Its Fragments: Colonial and Postcolonial Histories. Princeton: Princeton University Press.

Deol, Jeevan. 2002. 'Sex, Social Critique, and the Female Figure in Premodern Punjabi Poetry: Vāris Shāh's “Hir”, Modern Asian Studies 36, 1. 141-71.

Dobe, Timothy. 2015. Hindu Christian Faqir: Modern Monks, Global Christianity, and Indian Sainthood. NY: Oxford University Press.

Ernst, Carl. 1999. 'Chishti Meditation Practices of the Later Mughal Period.' In The Heritage of Sufism v. 3. Late classical Persianate Sufism (1501-1750), ed. L. Lewisohn, Oxford/Boston: One World. 344-57.

Ernst, Carl. 2003. 'The Islamization of Yoga in the "Amrtakunda” Translations', Journal of the Royal Asiatic Society 13, 2. 199-226.

Ernst, Carl. 2004 [1994]. Eternal Garden: Mysticism, History and Politics at a South Asian Sufi Center. Delhi: Oxford University Press.

Ernst, Carl. 2005. 'Situating Sufism and Yoga', Journal of the Royal Asiatic Society, 15, 1. 15-43.

Ernst, Carl. 2016. 'The Limits of Universalism in Islamic Thought: The Case of Indian Religions.' In Refractions of Islam in India: Situating Sufism and Yoga, New Delhi: Sage. 401-23.

Fenech, Louis. 2002. 'Contested Nationalisms; Negotiated Terrains: The Way Sikhs Remember Udham Singh “Shahid” (1899-1940)', Modern Asian Studies 36, 4. 827-70.

Fuchs, Martin. 2015. 'Processes of Religious Individualisation: Stocktaking and Issues for the Future', Religion 45, 3. 330-343.

Fuchs, Martin et al. 2016. 'Religious individualization in historical perspective: Research program 2014-2017.' In First Results of the Second Funding Period of the Research Group 'Religious Individualisation in Historical Perspective' (2013-2015): A Reader, ed. R. Suitner, Erfurt: Max Weber Centre, Universität Erfurt. 9-24.

Gaur, Ishwar Dayal. 2009. Society, Religion and Patriarchy: Exploring Medieval Punjab through Hir Waris. New Delhi: Manohar.

Gilmartin, David. 1988. 'Customary Law and Shariat in British Punjab.' In Shariat and Ambiguity in South Asian Islam, ed. K. P. Ewing, Berkeley: University of California Press. 33-62.

Green, Nile. 2008a. 'Making Sense of "Sufism" in the Indian Subcontinent: A Survey of Trends', Religion Compass 2/6. 1044-61.

Green, Nile. 2008b. 'Breathing in India c. 1890', Modern Asian Studies 42, 2/3. 283-315.

Hatley, Shaman. 2007. 'Mapping the Esoteric Body in the Islamic Yoga of Bengal', History of Religions 46, 4. 351-68.

Hare, James. 2011. 'Contested Communities and the Re-imagination of Nābhādās' Bhaktamāl.' In Time, History and the Religious Imaginary in South Asia, ed. A. Murphy, London: Routledge. 150-66.

Hawley, J. S. 2011. 'The four sampradays: Ordering the Religious Past in Mughal North India', South Asian History and Culture 2, 2.160-83. 
Hawley, J. S. 2015. A Storm of Songs: India and the Idea of the Bhakti Movement. Cambridge, MA: Harvard University Press.

Horstmann, Monika. 2009. Der Zusammenhalt der Welt: Religiöse Herrschaftslegitimation und Religionspolitik Mahārājā Savāĩ Jaisinghs (1700-1743). Wiesbaden: Otto Harrassowitz.

Horstmann, Monika. 2011. 'Theology and Statecraft', South Asian History and Culture 2, 2. 184-204. Huntington, Samuel P. 1993. 'The Clash of Civilizations?', Foreign Affairs 72.3. 22-49.

Jones, Kenneth. 1981. 'Religious Identity and the Indian Census.' In The Census in British India: New Perspectives, ed. N. G. Barrier, New Delhi: Manohar. 73-101.

Lorenzen, David. 1978. 'Warrior Ascetics in Indian History', Journal of the American Oriental Society $98,1.61-75$.

Lorenzen, David. 1999. 'Who Invented Hinduism?', Comparative Studies in Society and History 41, 4. 630-59.

Malinar, Angelika. 2015. 'Religious Pluralism and Processes of Individualisation in Hinduism', Religion 45, 39. 386-408.

Mann, Gurinderpal. 2018. 'Jat Masculinity and Deviant Femininity in a Punjabi Romantic Epic: Exploring Gender through Waris Shah's Hīr.' M.A. Thesis, Department of Asian Studies Faculty of Graduate \& Postdoctoral Studies, University of British Columbia.

Matringe, Denis. 2003. 'Hir Waris Shah.' In On Becoming an Indian Muslim: French Essays on Aspects of Syncretism. ed. and trans. M. Waseem, Delhi: Oxford University Press. 209-37.

Mir, Farina. 2006. 'Genre and Devotion in Punjabi Popular Narratives: Rethinking Cultural and Religious Syncretism', Comparative Studies in Society and History 48, 3. 727-58.

Mir, Farina. 2010. The Social Space of Language: Vernacular Culture in British Colonial Punjab. Berkeley: University of California Press.

Murphy, Anne. 2012a. 'The gurbilas literature and the idea of “religion”.' In Punjab Reconsidered: History, Culture, and Practice, eds. A. Malhotra, F. Mir, New York/New Delhi: Oxford University Press. 93-115.

Murphy, Anne. 2012b. The Materiality of the Past: History and Representation in Sikh Tradition. NY: Oxford University Press.

Murphy, Anne. 2015. 'The uses of the "folk": Cultural Historical Practice and the Modernity of the Guga Tradition', South Asian History and Culture 6, 4. 441-61. (Reprinted as 2016. 'Uses of the Folk: cultural historical practice and the Guga tradition.' In Cultural Studies in India, eds. R. Nayar, P. Syal, A. Kumar, New York: Routledge. 117-38.)

Murphy, Anne. 2018a. 'Writing Punjabi Across Borders.' In South Asian History and Culture. (Available online but final issue information not yet available. https://doi.org/10.1080/194 72498.2017.1411049.)

Murphy, Anne. 2018b. 'Thinking beyond Aurangzeb and the Mughal State in a late 18th century Punjabi Braj source.' In Journal of the Royal Asiatic Society 28, 3.537-554. Part of a special issue entitled 'From Outside the Persianate Center: Vernacular Views on "Alamgir”', eds. A. Murphy, H. Pauwels.

Murphy, Anne. 2018c. 'At a Sufi-Bhakti Crossroads: Gender and the politics of satire in early modern Punjabi Sufi literature', Archiv orientální (Journal of African and Asian Studies) 86. 243-268.

Murphy, Anne. 2019. 'Punjabi in the (late) Vernacular Millennium.' In Early Modern India: literature and images, texts and languages, eds. M. Burger \& N. Cattoni, Heidelberg, Berlin: CrossAsia-eBooks. 305-328.

Murphy, Anne and Pegah Shahbaz. Forthcoming. 'Punjabi and Persian versions of the tale of Hïr-Rañjhā: Religion in translation in early modern South Asia.' 
Nayar, Kamala Elizabeth; Sandhu, Jaswinder Singh. 2007. The socially involved renunciate: Guru Nānak's Discourse to the Nāth yogis. Albany: State University of New York Press.

Nelson, Matthew. 2011. In the Shadow of Shari'ah: Islam, Islamic Law, and Democracy in Pakistan. New York: Columbia University Press.

Nicholson, Andrew J. 2010. Unifying Hinduism: Philosophy and Identity in Indian Intellectual History. Columbia University Press.

Nicholson, Andrew J. 2013. 'Is Yoga Hindu?: On the Fuzziness of Religious Boundaries', Common Knowledge 19, 3. 490-505.

Oberoi, Harjot. 1994. The Construction of Religious Boundaries: Cultural, Identity, and Diversity in the Sikh Tradition. Chicago: University of Chicago Press.

Orsini, Francesca. 2010. 'Introduction.' In Before the Divide: Hindi and Urdu Literary Culture, ed. F. Orsini. Hyderabad: Orient BlackSwan. 1-20.

Orsini, Francesca. 2012. 'How to do multilingual history?', Indian and Economic Social History Review 49, 2. 225-46.

Otto, Bernd. 2017. 'Magic and Religious Individualisation: On the Construction and Deconstruction of Analytical Categories in the Study of Religion'. Historia Religionum 9. 29-52.

Padam, Piārā Sińgh (ed.). 1998 [1977]. Hīr Vāris Shāh. New Delhi.

Pauwels, Heidi. 2009. 'The Saint, the Warlord, and the Emperor: Discourses of Braj Bhakti and Bundelā Loyalty', Journal of the Economic and Social History of the Orient 52. 187-228.

Pennington, Brian. 2005. Was Hinduism Invented? Britons, Indians, and the Colonial Construction of Religion. New York: Oxford University Press.

Pinch, William R. 1999. 'History, Devotion and the Search for Nabhadas of Galta.' In Invoking the Past: The Uses of History in South Asia, ed. D. Ali, Delhi: Oxford University Press. 367-99.

Pinch, William R. 2006. Warrior Ascetics and Indian Empires. Cambridge: Cambridge University Press.

Robinson, Frances. 2008. 'Islamic Reform and Modernities in South Asia', Modern Asian Studies 42, 2/3. 259-81.

Šābir, Śarīf (ed.). 1986. Hīr Vāriš Śāh. Lahore: Progressive Books.

Shackle, Christopher. 1992. 'Transition and Transformation in Vāris Shāh's Hīr.' In The Indian Narrative: Perspectives and Patterns, eds. C. Shackle, R. Snell, Wiesbaden:

0. Harrassowitz. 241-63.

Shackle, Christopher. 2000. 'Beyond Turk and Hindu: Crossing the Boundaries in Indo-Muslim Romance.' In Beyond Turk and Hindu: Rethinking Religious Identities in Islamicite South Asia, eds. D. Gilmartin, B. Lawrence, Gainesville, FL: University of Florida Press. 55-73.

Shackle, Christopher. 2015. 'Introduction.' In Bulhe Shah, Sufi Lyrics, ed. and transl. C. Shackle, Cambridge: Murty Classical Library of India/Harvard University Press. vii-xxx.

Shah, Bulhe. 2015. Sufi Lyrics, ed. and trans. C. Shackle, Cambridge: Harvard University Press.

Shah, Nafisa. 2016. Honour and Violence: Gender, Power, and Law in Southern Pakistan. NY: Berghahn.

Singh, Pankaj. 2000. Representing Woman: Tradition, Legend and Panjabi Drama. Shimla: Indian Institute of Advanced Study.

Sital, Jit Singh (ed.). Undated. HirrVaris. Patiala: PEPSU Book Depot.

Stewart, Tony K. 2001. 'In Search of Equivalence: Conceiving Muslim-Hindu Encounter through Translation Theory', History of Religions 10, 3. 260-87.

Syed, Najm Hosain. 2006 [1968]. Recurrent Patterns in Punjabi Poetry. Lahore: Justin Group Printers.

White, David. 2009. Sinister Yogis. Chicago: The University of Chicago Press. 